\title{
The impact of the covid-19 pandemic on retail consumer behavior
}

\author{
Sayyida ${ }^{1}$, Sri Hartini ${ }^{2}$, Sri Gunawan ${ }^{3}$, Syarief Nur Husin ${ }^{4}$ \\ 1,2,3Airlangga University, Surabaya, Jawa Timur \\ ${ }^{4}$ Coventry University, United Kingdom

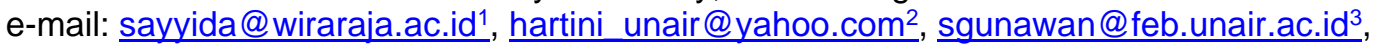 \\ syariefnus@uni.coventry.ac.uk ${ }^{4}$
}

\begin{abstract}
To cite this document :
Sayyida, S., Hartini, S., Gunawan, S., \& Husin, S. (2021). The Impact of the Covid-19 Pandemic on Retail Consumer Behavior. Aptisi Transactions on Management (ATM), 5(1), 79-88.
\end{abstract}

DOI :

https://doi.org/10.33050/atm.v5i1.1497

\section{Abstract}

The COVID-19 pandemic that occurred throughout 2020 has an impact on economic sector. Consumers tend to use online channels to reduce face-to-face contact with marketers or other consumers. On the other hand, the consumer's need to see, touch and feel a product directly is only available in physical stores. This study aims to analyze the impact of the COVID-19 pandemic on retail consumer behavior. This study uses quantitative methods with secondary data sources obtained from several countries including the United States, England, Germany, France, Canada and Latin America. The results show that the shopping trends during the COVID-19 pandemic are webrooming and pure online shopping. Retail sales data in these countries shows that retail sales in physical stores exceed $70 \%$ of total retail sales and retail e-commerce sales are less than $30 \%$ of total retail sales. This research is expected to be useful for marketers in improving retail marketing strategies during the COVID-19 pandemic.

Keyword: COVID-19, Webrooming, Pure Online Shopping, Consumer Behavior

\section{Introduction}

Digital media is the right choice for sharing information. Digital information spreads easily, cheaply and quickly. Digital information can reach its target without being limited by time and place [1]. The digital media is a medium for sharing information related to products or services, whether sourced from marketers or consumers. Marketers can offer their products quickly and cheaply. The ease of sharing digital information makes it easy for consumers to share their information regarding their shopping experience. Consumers also easily and cheaply get digital information [3]. Consumers trust more in information shared by other consumers such as online consumer reviews (OCR) [4]. Online consumer information affects nearly $50 \%$ of retail sales [2]. Online consumer reviews are another consideration for consumers in making purchasing decisions [5]. Consumers take advantage of digital media and / or other media in the shopping process to get benefits that are more appropriate to their needs. Various media used by consumers in shopping, hereinafter referred to as omnichannel.

There are four consumer behaviors in the omnichannel era according to the types and needs of consumers in shopping. The four consumer behaviors include pure offline shopping, showrooming, webrooming, and pure online shopping [6]. Pure offline shopping is shopping behavior that utilizes traditional media to carry out the shopping process [6]. Consumers who carry out shopping behavior with pure online shopping are called pure online shoppers. 
Showrooming and webrooming are shopping behaviors that combine digital media with physical stores. Showrooming is a shopping behavior that uses physical stores as a place to find information on products or services and then make purchases at online stores [7], [8]. Consumers who perform showrooming behavior are called Showroomers. Webrooming is shopping behavior that uses digital channels to search for information related to products or services and then make purchases at physical stores [7], [8]. Showrooms and webroomers are usually done to find the cheapest prices and also ensure the condition of the goods directly [9], [10]. The last shopping behavior is pure online shopping, namely shopping behavior that utilizes digital media in all shopping processes [6]. Consumers who are looking for product or service information on digital channels and also making purchases through digital channels are called pure online buyers. It is reported that $52 \%$ of consumers are webroomers and $30 \%$ of consumers are showroomers [10], the rest are pure online buyers and pure offline buyers. Showroomers are the shopping behavior that consumers are most interested in in the omnichannel era, but the Corona virus SARS-CoV2 outbreak has had many impacts on consumer behavior.

The Corona SARS-CoV-2 (COVID-19) has spread so fast that it has become a global pandemic since March 2020 [12]. The COVID-19 pandemic has claimed many victims in various countries around the world. The COVID-19 pandemic began to hit the world in the first quarter of 2020. Many countries have implemented territorial restrictions to reduce the spread of COVID19. Health protocols are implemented to prevent the worsening of the COVID-19 pandemic conditions. One health protocol that all citizens must adhere to is social distancing. The COVID19 pandemic has an impact on various sectors including the economic sector. The pandemic that occurred destroyed the world economy. The application of regional lockdowns and social distancing has an impact on human behavior. People spend more time at home, work from home, study from home, and have less contact with other people.

The COVID-19 pandemic that occurred throughout 2020 has become a new history for human civilization. This also happens to consumer behavior. Consumers tend to take advantage of online media to carry out various processes in shopping. The amount of time at home provides an opportunity for consumers to find product information digitally. Some consumers will still make purchases digitally after receiving information from digital media (pure online shopping), but others will make purchases at physical stores after receiving digital information (webrooming) for direct product confirmation. As stated in previous studies, online stores are not able to provide all the needs of consumers like those in traditional / physical stores. Consumer needs that are not found in online stores include the need to see, touch, and feel the quality of the product directly [13].

Many sources say that online retail is increasing during the Covid-19 pandemic [14]-[20], however, the consumer's need to touch exists only in traditional retail [13]. This makes the authors interested in conducting research related to consumer behavior in the era of the COVID-19 pandemic. This study aims to analyze the impact of the Covid-19 pandemic on retail consumer behavior. The results of this study are expected to be useful for marketers in improving marketing strategies according to consumer needs during the COVID-19 pandemic, which is still unclear when it will end.

\section{Research Method}

\section{Literature review \\ Virus SARS-CoV-2 (COVID-19)}

The city of Wuhan - China became the first place for the discovery of the SARS-CoV-2 corona virus (COVID-19) which quickly spread to various countries in the world [11], [21]. A tense atmosphere occurred in the city of Wuhan in December 2019 because of the large number of fatalities due to the virus. In early 2020 , the virus spread rapidly to various countries in the world and became a global pandemic. The large number of victims who have died due to the global COVID-19 pandemic has forced many countries to carry out regional lockdowns, social distancing, closure of workplaces, and also educational institutions [22]. This global pandemic has an impact on various sectors, including the economic sector. Ecommerce has gotten stronger with increased sales during the lockdown period. E-commerce stores such as Happy Fresh and Lazada reported that their sales increased by $10 \%$ to $15 \%$ during the Movement Control Order period [14]. People around the world are forced to carry out social distancing to reduce the spread of the virus so that their condition does not get worse. This COVID-19 pandemic occurs 
throughout 2020 without anyone knowing when it will end. 2020 is the year of a new civilization for humans, because the COVID-19 pandemic that is sweeping the world forces humans to adopt new behaviors to suppress the spread of the virus. This behavior change also occurs in consumer behavior in retail trade.

\section{Consumer Behavior}

Consumer behavior in the digital era is divided into four groups, namely pure offline shopping, pure online shopping, showrooming and webrooming [6]. Pure offline shopping and pure online shopping are shopping behaviors that use only one channel in carrying out the entire shopping process. Pure offline shopping is shopping behavior that looks for information in physical stores and also makes purchases at physical stores [6]. Pure offline shopping only uses offline channels in carrying out a series of shopping processes. Pure offline shopping is a traditional shopping behavior. In contrast, pure online shopping is a shopping behavior that uses digital media in the entire shopping process. Pure online shopping is a shopping behavior that uses digital media to find product information to be purchased then make purchases also in digital media [6]. Consumers who shop with pure online shopping are called pure online shoppers, while consumers who shop with pure offline shopping are called pure offline shoppers.

Webrooming and showrooming are shopping behaviors that are trending in the omnichannel era [23], [24]. Showrooming and webrooming are shopping behaviors that combine online and offline channels in the shopping process [25]. Showrooming is a shopping behavior that uses physical stores to find product information and then make purchases at online stores [7], [8]. Consumers who shop through showrooming are called showroomers. Webrooming is a shopping behavior that uses digital media to find product information and then make purchases at physical stores [7], [8]. Consumers who perform webrooming behavior are called webroomers. Showroomers and webroomers usually aim to save money and / or ensure the actual condition of the item [9], [10]. In 2018, it was reported that $52 \%$ of consumers were webroomers and $30 \%$ of consumers were showroomers [10].

\section{Methods}

This research uses quantitative research with secondary data sources. This data comes from e-commerce data before and during the global COVID-19 pandemic. Retail sales data from various countries, including the United States, United Kingdom, Germany, France, Canada and Latin America. Descriptive analysis was conducted to describe the impact of the COVID-19 pandemic on retail consumer behavior. The proportion of online versus offline retail sales of total retail sales is presented to describe consumer behavior in making purchases both online and offline. Furthermore, an analysis of consumer behavior trends during the COVID-19 pandemic is carried out.

\section{Result and discussion}

Based on secondary data from several countries, it appears that online retail sales will experience an increase in 2020 . One of the factors that are considered to be influencing the increase in retail e-commerce sales is the COVID-19 pandemic, which is a worldwide problem. The COVID-19 pandemic has impacted various sectors including the retail trade sector. Social distancing and regional lockdowns are factors that trigger an increase in retail e-commerce sales. Consumers avoid face-to-face contact and tend to turn to digital media or online media to suppress the spread of the virus. This increase in online retail sales occurred globally as seen in e-commerce data in the following countries.

\section{Consumer Behavior in the United States}

The United States is the largest e-commerce country in the world based on several key categories in 2019 [26]. The number of online shoppers in the country in 2019 amounted to 258.5 million or $78.9 \%$ of the total population [26]. On the other hand, online retail sales in the United States in 2018 reached $9.9 \%$ of total retail sales in the country [17]. Online retail sales increased $0.2 \%$ in 2019 to $11 \%$ of total retail sales [17]. This shows that even though nearly $80 \%$ of Americans have shopped online, they have not abandoned shopping in physical stores. Nearly $90 \%$ of retail spending in the country is shopping at physical / offline stores. It could be that almost 
all consumers who are registered as online buyers also make traditional purchases more often. This is the reason offline sales are still quite large.

The COVID-19 pandemic that is sweeping the world is contributing to an increase in online retail sales in the United States. The rapid spread of the virus forces people to exercise social distancing [12], [22]. Many consumers are starting to turn to digital media to replace faceto-face activities. This also happens in retail trade. Consumers tend to use digital media in the shopping process, such as in finding product information and / or making purchases. Online retail sales in the United States increased significantly compared to the previous year. The proportion of online retail sales from total retail sales in 2020 was $14.5 \%$, an increase of $3.5 \%$ from 2019 [17]. The highest proportion of online retail sales to total retail sales occurred in the second quarter of 2020 which reached $16.2 \%$ [27]. This happens because of unusual consumer behavior. Consumers make large purchases online because of excessive concern due to the circulation of information about market disruptions during the COVID-19 pandemic [12]. The proportion of online retail sales in the United States declined again in the third quarter of 2020 to $14.3 \%$ [27].

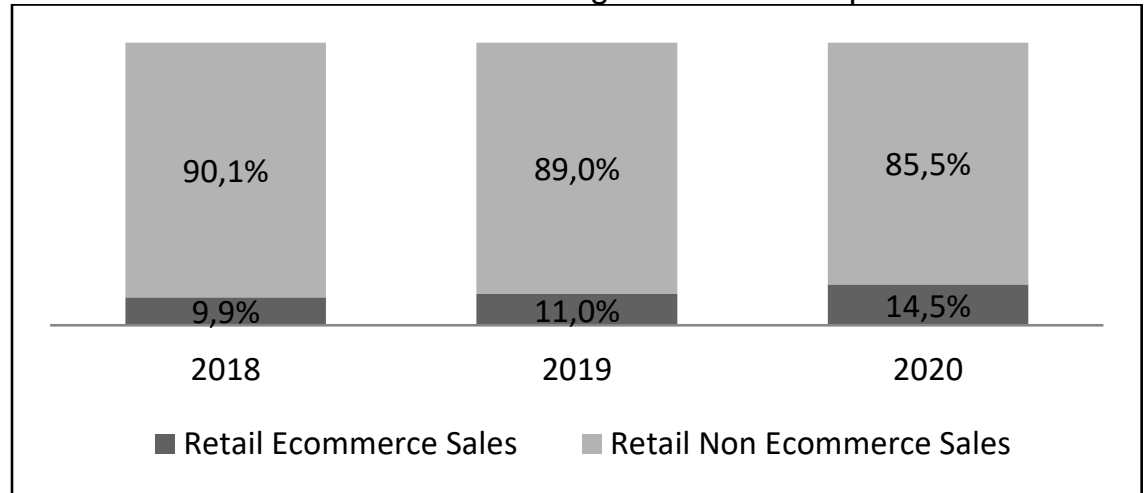

Figure 1. Percentage of Online versus Offline Retail Sales in the United States

Figure 1 shows the proportion of online versus offline retail sales of total retail sales in the United States. Figure 1 shows offline retail sales in the United States in 2018, 2019, and 2020 amounting to $90.1 \%, 89.0 \%$ and $85.5 \%$ of total retail sales in the country, respectively. This proportion of offline retail sales is very large when compared to online retail sales. This shows that social restrictions due to the COVID-19 pandemic have had little effect on purchasing behavior. Only a 3.5\% decrease in offline purchases. Consumers still tend to choose purchases traditionally or in physical stores. The shift in consumer behavior to digital media can occur in the pre-purchase process, which is the process of searching for information. During social distancing, consumers tend to look for information digitally, either product information from marketers or other consumers. Advances in technology have made it easier for consumers to share their shopping experiences with the aim of helping other consumers [28]. Information from other consumers becomes a consideration in making purchase decisions [5], [29]. Pandemic conditions that are troubling the world force consumers to engage in social distancing by increasing their stay at home. Various activities are carried out from home such as working, studying, and even shopping from home. Consumers who live at home can easily, cheaply, and quickly find out about the shopping experiences of other consumers. Some consumers will make purchases online after receiving information online (pure online shopping) and some other consumers will make purchases at physical stores (webrooming). Referring to the existing data, the high retail sales in physical stores shows that consumer-preferred webrooming behavior. Given the COVID-19 pandemic, it is very difficult to carry out the whole shopping process traditionally (pure offline shopping). This increase in online purchases was made possible due to an increase in pure online shopping behavior because during the COVID-19 pandemic it was very difficult to find product information in traditional stores. This fact shows that the behavior of pure offline shopping and showrooming shopping is starting to be avoided by consumers in order to reduce face-to-face activities for activities that are not important and / or activities that can be diverted to digital media. Searching for information is an activity that is very possible in digital media because information in digital media can reach targets cheaply, easily and quickly. Furthermore, some consumers make direct purchases at physical stores to confirm products directly or want to bring products immediately (without waiting for the delivery process). The description above shows that the shopping trend during the COVID-19 pandemic is webrooming and pure online shopping. 


\section{Consumer Behavior in the United Kingdom}

United Kingdom (UK) is the third largest e-commerce market after the United States and China. It is reported that the number of online shoppers in the UK in 2019 reached $79.8 \%$ of the total population. The number of online shoppers in the UK is the third largest in the world after Sweden and Korea [26]. UK online retail sales data in 2020 amounted to $27.5 \%$ of total retail sales [15]. The proportion of online retail sales from total retail sales has increased by $5.7 \%$ from the previous year. The same data source shows that in 2019 online retail sales reached $21.8 \%$ of total retail sales. Another data source states that online retail sales in 2018 reached $18 \%$ of total retail sales in the UK [30]. This data shows that the proportion of online retail sales of total retail sales in 2019 has increased by $3.8 \%$ compared to 2018 .

The COVID-19 pandemic that occurred globally in early 2020 is one of the triggers for the increasing proportion of online retail sales from total retail sales. This online retail sales peaked in the second quadrant of 2020 at $31.4 \%$ and decreased again in the third quadrant in 2020 to $27.0 \%$. The increase in the second quadrant is the impact of unusual consumer behavior because consumers are worried that there will be market disruptions during a pandemic. On the other hand, retail sales in traditional stores have decreased. In 2018 , offline retail sales reached $82 \%$. Furthermore, offline retail sales in 2019 and 2020 were $78.2 \%$ and $72.5 \%$, respectively.

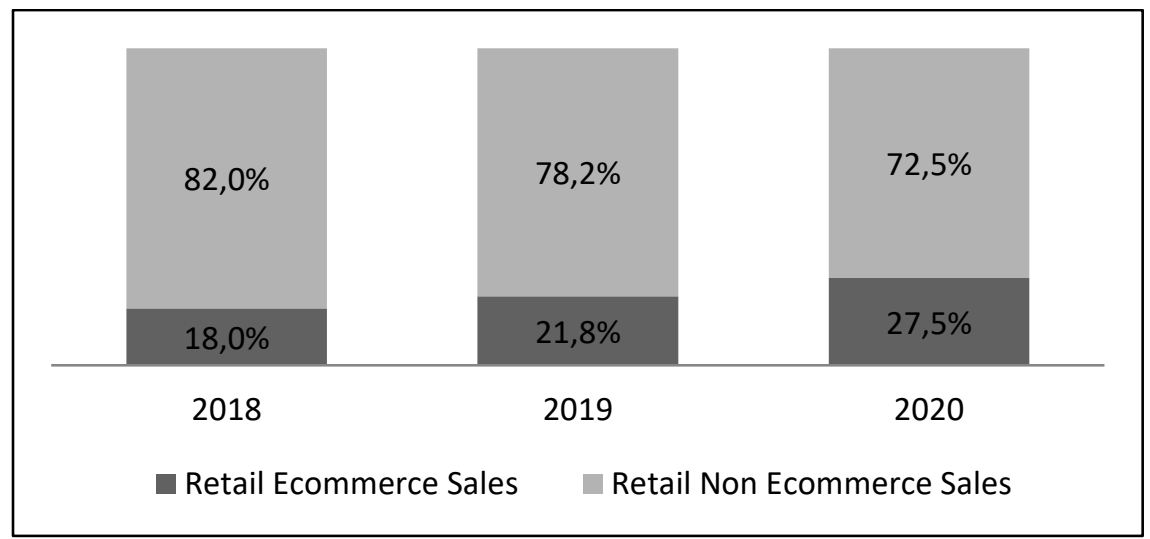

Figure 2. Percentage of Online versus Offline Retail Sales in the United Kingdom

Figure 2 shows that the COVID-19 pandemic that occurred during 2020 did have an impact on consumer spending behavior in the UK. UK consumers shopping online saw a bigger increase than the previous year. The increase in online retail sales due to the COVID-19 pandemic is very small when compared to offline retail sales. Although online retail has increased, offline retail sales are still quite large. Online retail sales are above $70 \%$ of total retail sales. In line with previous research [13], the data in Figure 2 shows that consumers have a need to ensure products directly so that in social distancing conditions consumers continue to shop at physical/offline stores. Consumers tend to look for complete product information on digital media to reduce the duration of face to face with marketers and other consumers when making purchases. Consumers evaluate products and rely on digital information from other consumers for consideration [5] before making a purchase at a physical store. Based on descriptions of online and offline retail sales during the COVID-19 pandemic, it can be seen that consumer trends during the COVID-19 pandemic in the UK are looking for information online to then make offline purchases or webrooming. The increase in online sales during the COVID-19 pandemic shows that the tendency of consumers to engage in pure online shopping behavior is also increasing. This is due to the obligation of consumers to carry out social distancing in order to reduce the spread of the virus. During this pandemic, it is increasingly possible for consumers to get information online easily, cheaply and quickly [1] from home without having to do face to face.

\section{Consumer Behavior in Germany}

Germany is the fifth largest e-commerce country in the world [26]. The proportion of online retail sales of total retail sales in 2019 is $8.9 \%$ [19]. The global COVID-19 pandemic in 2020 is 
one of the factors driving the increase in online retail sales in Germany. The proportion of online retail sales in 2020 increased by $2.3 \%$ to $11.2 \%$ compared to 2019 [19].

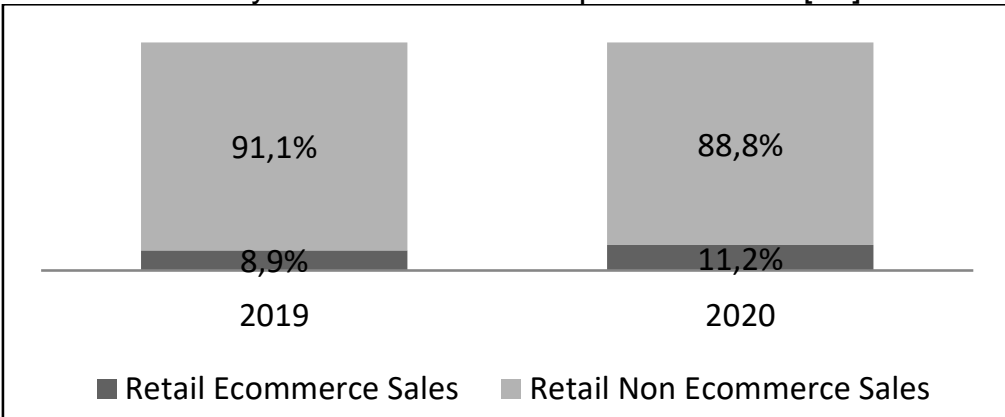

Figure 3. Percentage of Online versus Offline Retail Sales in Germany

Figure 3 shows offline retail sales in 2019 which reached $91.1 \%$ of total retail sales. This shows that even though Germany is a fairly large e-commerce country, traditional retail / physical stores are still very strong so that they are able to sell their retail products exceeding $90 \%$ of the needs of the people in that country. The COVID-19 pandemic in 2020 has shifted people's behavior to the digital world, but buying behavior still tends to be in physical stores. This shows that the COVID-19 pandemic has not had a major impact on consumer behavior in making purchases but has an impact on consumer behavior in seeking product information. Refers to four consumer behaviors in the omnichannel era, that are pure online shopping, showrooming, webrooming, and pure offline shopping [6] as well as the obligation of the community to carry out social distancing during a pandemic, the consumer behavior that has begun to be abandoned is pure offline shopping and showrooming. Pure online shopping is extremely difficult during the global COVID-19 pandemic as everyone is forced to reduce face-to-face meetings. Showrooming has also begun to be avoided because information searches are easier to find in digital media without having to come face to face with marketers and / or other consumers. The description above shows that the shopping trend during the COVID-19 pandemic is webrooming and pure online shopping.

\section{Consumer Behavior in France}

France is the sixth largest e-commerce country in the world [26]. In 2019, online retail sales in France were 9.2\% of total retail sales [18]. The COVID-19 pandemic throughout 2020 was able to increase the proportion of online retail sales by $3 \%$ to $12.2 \%$ of total retail sales. This online retail sale is relatively small when compared to the proportion of offline retail sales which almost reaches $90 \%$ of total retail sales. This provides evidence that changing consumer behavior during the COVID-19 pandemic, which tends to use digital media to replace face-to-face, only adds to $3 \%$ of retail sales. Changes in consumer behavior in France that tend to shift to digital media are a process of searching for information on products / services. This is possible because of the ease of digital information facilities at this time as well as the many consumer reviews about their shopping experience that are shared online. Consumers trust more in online consumer review information because it comes from the shopping experiences of other consumers [2].

The COVID-19 pandemic has an impact on consumer shopping behavior. Consumers in this country tend to use digital media to find information related to products before making a purchase. The search for digital information is carried out to reduce direct contact with marketers. Only a small proportion of consumers continue to buy online and some continue to buy at physical stores after receiving digital information. Consumers choose to make purchases at physical stores with the aim of increasing satisfaction in shopping [31]. Shopping satisfaction can be obtained by seeing, feeling, and even trying the product directly. The data presented in Figure 4 provides evidence that consumers tend to make purchases offline. The existence of social distancing during the pandemic which requires consumers to reduce direct contact with marketers or other consumers as described above shows that the shopping trend in France is webrooming and pure online shopping. Consumers look for product information online from home during social distancing, but still make offline purchases to get shopping satisfaction (webrooming). Several other consumers make online purchases from home after receiving information online (pure online shopping). 


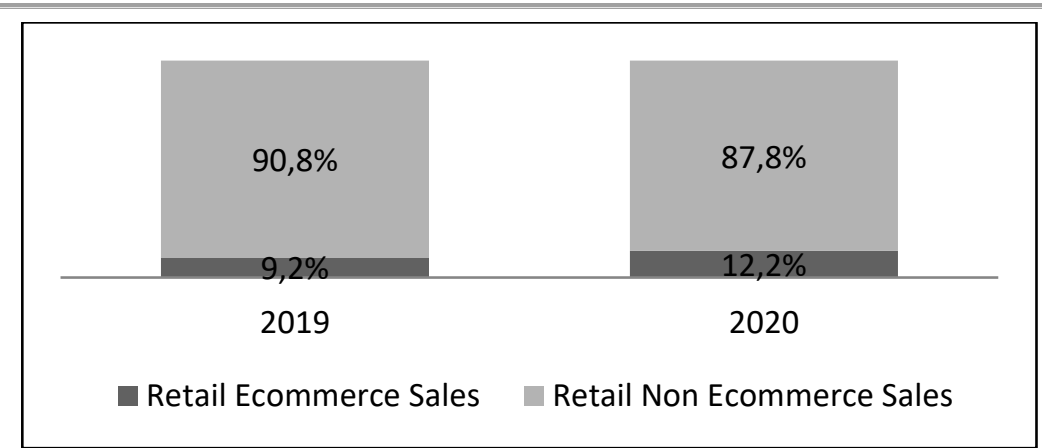

Figure 4. Percentage of Online versus Offline Retail Sales in France

\section{Consumer Behavior in Canada}

The 2019 Global E-commerce Market Ranking listed Canada as the seventh top ecommerce country in the world [26]. Online retail sales in the country are quite small compared to retail sales in physical stores. Figure 5 shows the proportion of online versus offline retail sales of total retail sales in Canada. In 2019, the proportion of online retail sales reached $6.8 \%$ of total retail sales [16], in contrast, retail sales in physical stores accounted for $93.2 \%$ of total retail sales. The COVID-19 pandemic has not had a major impact on online retail sales.

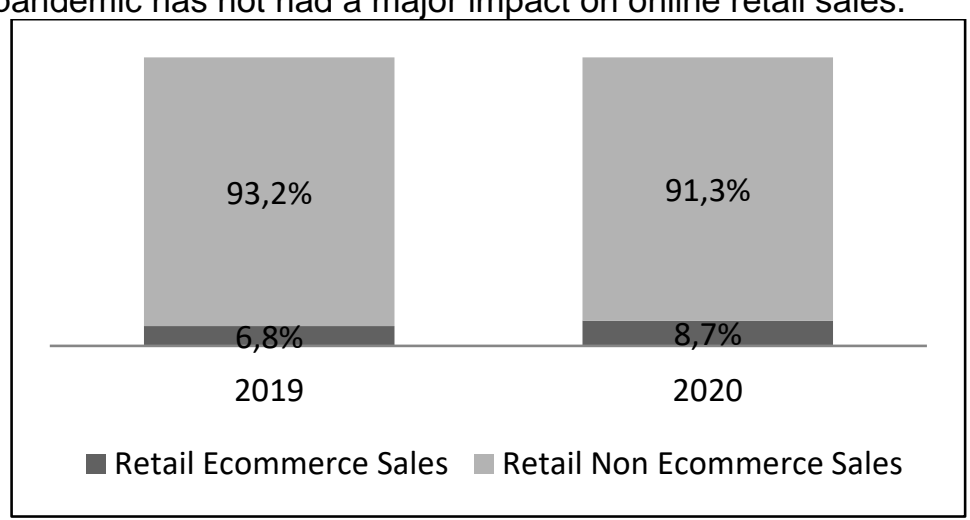

Figure 5. Percentage of Online versus Offline Retail Sales in Canada

The data in Figure 5 shows the proportion of online retail sales of $8.7 \%$ [16] an increase of $1.9 \%$ from 2019. In line with the previous description, the global COVID-19 pandemic has greatly affected consumer behavior, especially in seeking product information before making a purchase. Social distancing that must be done by the community to reduce the spread of the virus, as well as technological advances today allow consumers to evaluate products using digital information before making a purchase. In fact, consumers tend to make purchases at physical stores. More than $90 \%$ of retail sales are made in physical stores. This retail sales data in Canada confirms the results of previous studies [13] that online stores are not able to provide all the needs of consumers like those in physical stores. The description shows that consumer shopping trends in Canada are still using physical stores for shopping after receiving digital information (webrooming), although there has been an increase in online purchases originating from pure online shoppers.

\section{Consumer Behavior in Latin America}

Latin America is a country with very little online retail sales. In 2018 , online retail sales in this country were recorded at only $3.5 \%$ of total retail sales and $4,4 \%$ in 2019 [20]. During the COVID-19 pandemic in 2020, the proportion of online retail sales increased by $1.2 \%$ from 2019 to $5.6 \%$ of total retail sales [20]. 


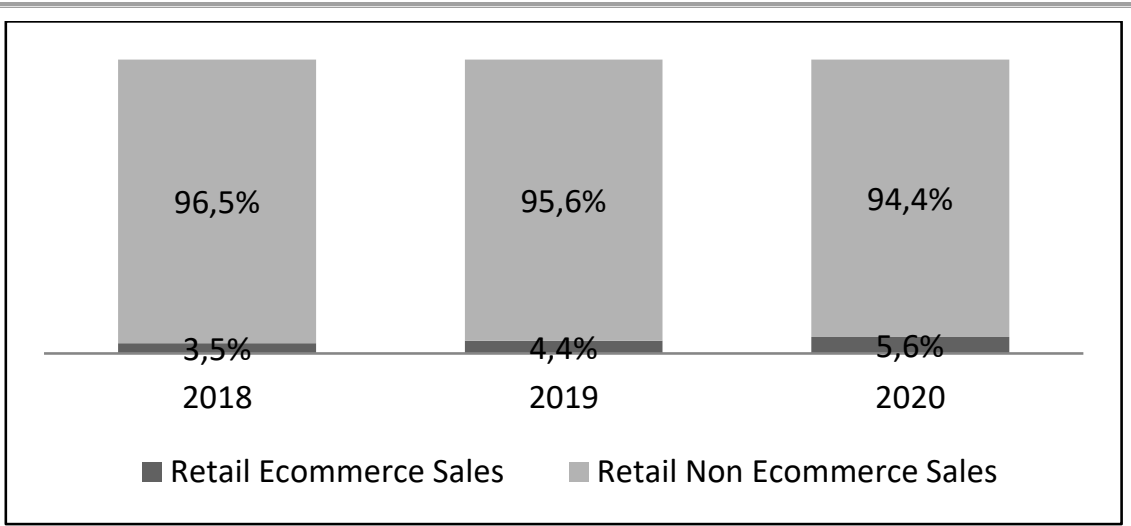

Figure 6. Percentage of Online versus Offline Retail Sales in Latin America

Figure 6 shows that the proportion of offline retail sales is very large. The proportion of retail sales in physical stores in 2018, 2019 and 2020 was $96.5 \%, 95.6 \%$ and $94.4 \%$ of total retail sales in Latin America, respectively. This proves that the social distancing that must be carried out by the community during the COVID-19 pandemic is unable to prevent consumers from making purchases at physical stores. Consumers tend to make purchases at offline stores to get satisfaction with consumer's Need for Touch [32]. Referring to Figure 6 and the condition of the COVID-19 pandemic which requires consumers to reduce direct contact with retailers, it can be concluded that changes in consumer behavior occur at the information seeking stage. Consumers tend to search for information digitally and then make purchases at physical stores (webrooming). The slight increase in online sales shows that there is an increase in the behavior of consumers who shop online after receiving digital information (pure online shopping) during the COVID-19 pandemic. This description shows that the trend of consumer behavior in Latin American countries is webrooming and pure online shopping.

\section{Conclusion}

The global COVID-19 pandemic throughout 2020 has an impact on consumer behavior. Social distancing during the COVID-19 pandemic forced many people to turn to digital media. Consumers tend to use digital information to find product information before buying. Referring to online retail sales data in several countries in the world, including the United States, United Kingdom, Germany, France, Canada and Latin America, shows that online retail sales are very small when compared to offline retail sales. Global online retail sales are less than $30 \%$ of total retail sales. In other words, retail sales in physical stores are very large, which is more than $70 \%$ of total retail sales.

The COVID-19 pandemic is impacting online retail sales, but it is quite small. The increase in global online retail sales was less than $10 \%$ of total retail sales or $10 \%$ to $15 \%$ of online retail sales prior to the COVID-19 pandemic. The highest increase in online retail sales during the pandemic occurred in the second quarter of 2020 and decreased again in the third quarter of 2020 . The peak of online retail sales during the pandemic is no more than $35 \%$ of total retail sales. The increase in online retail sales in the second quadrant of 2020 was caused by unusual purchasing behavior as consumers feared market disruptions due to the global COVID19 pandemic. The data analysis above shows a change in consumer behavior during the COVID19 pandemic, which tends to use digital information before making a purchase. Ease of accessing information online and also the pandemic conditions that force consumers to reduce direct contact with marketers make consumers choose to search for information online before making a purchase. The data also shows that consumers tend to make purchases at physical stores. The consumer's need to touch goods directly before they are purchased is only in physical stores. The consumer's need to touch is a consumer's need to ensure the goods directly in order to increase satisfaction in shopping. This is the reason consumers continue to shop at physical stores even during social distancing. From the description above, it can be concluded that the trend of consumer shopping behavior during the COVID-19 pandemic is webrooming and pure online shopping.

\section{REFERENCES}

[1] E. Greenberg and A. Kates, Strategic digital marketing: top digital experts share the 
formula for tangible returns on your marketing investment. McGraw-Hill Education, 2014.

[2] H. Chen, W. Duan, and W. Zhou, "The interplay between free sampling and word of mouth in the online software market," Decis. Support Syst., vol. 95, pp. 82-90, 2017, doi: 10.1016/j.dss.2017.01.001.

[3] J. Zhang, “Customer' Loyalty Forming Mechanism of O2O E-Commerce," Int. J. Bus. Soc. Sci., vol. 5, no. 5, pp. 164-169, 2014.

[4] C. Orús, R. Gurrea, and S. Ibáñez-sánchez, "The impact of consumers ' positive online recommendations on the omnichannel webrooming experience El impacto de las recomendaciones online positivas de los consumidores en la experiencia webrooming omnicanal," vol. 23, no. 3, pp. 397-413, 2019, doi: 10.1108/SJME-08-2019-0067.

[5] X. Shi and Z. Liao, "Online consumer review and group-buying participation: The mediating effects of consumer beliefs," Telemat. Informatics, vol. 34, no. 5, pp. 605-617, 2017, doi: 10.1016/j.tele.2016.12.001.

[6] R. Manss, K. Kurze, and R. Bornschein, "What drives competitive webrooming? The roles of channel and retailer aspects," Int. Rev. Retail. Distrib. Consum. Res., vol. 30, no. 3, pp. 233-265, 2020, doi: 10.1080/09593969.2019.1687104.

[7] S. Arora and S. Sahney, Webrooming behaviour: a conceptual framework, vol. 45, no. 78. 2017.

[8] C. Flavián, R. Gurrea, and C. Orús, "Feeling Confident and Smart with Webrooming: Understanding the Consumer's Path to Satisfaction," J. Interact. Mark., vol. 47, pp. 1-15, 2019, doi: 10.1016/j.intmar.2019.02.002.

[9] M. Marmol and V. Fernandez, "Trigger factors in brick and click shopping," Intang. Cap., vol. 15, no. 1, pp. 57-71, 2019, doi: 10.3926/ic.1364.

[10] PushOn, "showrooming - webrooming new report," 2018.

[11] N. Akhtar, M. Nadeem Akhtar, M. Usman, M. Ali, and U. Iqbal Siddiqi, "COVID-19 restrictions and consumers' psychological reactance toward offline shopping freedom restoration," Serv. Ind. J., vol. 40, no. 13-14, pp. 891-913, 2020, doi: 10.1080/02642069.2020.1790535.

[12] S. Laato, A. K. M. N. Islam, A. Farooq, and A. Dhir, "Unusual purchasing behavior during the early stages of the COVID-19 pandemic: The stimulus-organism-response approach," J. Retail. Consum. Serv., vol. 57, no. July, p. 102224, 2020, doi: 10.1016/j.jretconser.2020.102224.

[13] M. B. Baihaqi, "Alasan Belanja Offline Sulit Tergantikan dengan Belanja Online," Harian ekonomi neraca, 2018. http://www.neraca.co.id/article/102210/alasan-belanja-offlinesulit-tergantikan-dengan-belanja-online (accessed Feb. 18, 2019).

[14] K. Isa, J. M. Shah, S. T. Palpanadan, and F. Isa, "Malaysians' popular online shopping websites during movement control order (Mco)," Int. J. Adv. Trends Comput. Sci. Eng., vol. 9, no. 2, pp. 2154-2158, 2020, doi: 10.30534/ijatcse/2020/190922020.

[15] B. Fisher, "UK Ecommerce 2020: digital buying takes hold as pandemic decimates the high street," 2020. [Online]. Available: https://www.emarketer.com/content/ukecommerce-2020.

[16] P. Briggs, "Canada Ecommerce 2020 : Digital Retail Propelled by COVID-19 Quarantines," 2020. [Online]. Available: https://www.emarketer.com/content/canada-ecommerce-2020.

[17] A. Lipsman and Cindy Liu, "US Ecommerce 2020: COronavirus Boosts Ecommerce Forecast and Will Accelerate Channel-Shift," 2020. [Online]. Available: https://www.emarketer.com/content/us-ecommerce-2020.

[18] K. von Abrams, "France Ecommerce 2020 : Digital Sales Soar as Total Retail Suffers," 2020. [Online]. Available: https://www.emarketer.com/content/france-ecommerce-2020.

[19] K. von Abrams, "Germany Ecommerce 2020 : Digital Retail Prospers in the Coronavirus Era," 2020. [Online]. Available: https://www.emarketer.com/content/germany-ecommerce2020.

[20] M. Ceurvels, "America Ecommerce 2020 : How CIVID-19 Will Affect Growth and Sales in Argentina, Brazil and Mexico," 2020. [Online]. Available: https://www.emarketer.com/content/latin-america-ecommerce-2020.

[21] Z. Xu et al., "Pathological findings of COVID-19 associated with acute respiratory distress syndrome," Lancet Respir. Med., vol. 8, no. 4, pp. 420-422, 2020, doi: 10.1016/S22132600(20)30076-X. 
[22] R. M. Anderson, H. Heesterbeek, D. Klinkenberg, and T. D. Hollingsworth, "How will country-based mitigation measures influence the course of the COVID-19 epidemic?," Lancet, vol. 395, no. 10228, pp. 931-934, 2020, doi: 10.1016/S0140-6736(20)30567-5.

[23] C. Flavián, R. Gurrea, and C. Orús, "Combining channels to make smart purchases: The role of webrooming and showrooming," J. Retail. Consum. Serv., vol. 52, p. 101923, 2020, doi: 10.1016/j.jretconser.2019.101923.

[24] N. Viejo-Fernández, M. J. Sanzo-Pérez, and R. Vázquez-Casielles, "Different kinds of research shoppers, different cognitive-affective consequences," Spanish J. Mark. - ESIC, vol. 23, no. 1, pp. 45-68, 2019, doi: 10.1108/SJME-09-2018-0040.

[25] J. Y. M. Kang, "Showrooming, Webrooming, and User-Generated Content Creation in the Omnichannel Era," J. Internet Commer., vol. 17, no. 2, pp. 145-169, 2018, doi: 10.1080/15332861.2018.1433907.

[26] Eshopworld.com, "Global Ecommerce Market Ranking 2019," 2019. [Online]. Available: https://www.worldretailcongress.com/_media/Global_ecommerce_Market_Ranking_20 19_001.pdf.

[27] U.S. Bureau of the Census, "E-Commerce Retail Sales as a Percent of Total Sales [ECOMPCTSA]," FRED, Federal Reserve Bank of St. Louis, 2020. https://fred.stlouisfed.org/series/ECOMPCTSA (accessed Dec. 25, 2020).

[28] L. Liu, C. M. K. Cheung, and M. K. O. Lee, "An empirical investigation of information sharing behavior on social commerce sites," Int. J. Inf. Manage., vol. 36, pp. 686-699, 2016.

[29] Y. Chen and J. Xie, "Online Consumer Review: Word-of-Mouth as a New Element of Marketing Communication Mix," Manage. Sci., vol. 53, no. 3, pp. 477-491, 2008, doi: $10.1287 / \mathrm{mnsc} .1070 .0810$.

[30] M. Rhian, "'Table Internet sales as a percentage of total retail sales (ratio) (\%)'.," offoce for national statistics, 2020. https://www.ons.gov.uk/businessindustryandtrade/retailindustry/timeseries/j4mc/drsi.

[31] I.-P. Chiang, C.-Y. Lin, and C.-H. Huang, "Measuring The Effects of Online-to-Offline Marketing," Contemp. Manag. Res., vol. 14, no. 3, pp. 167-189, 2018, doi: 10.7903/cmr.18462.

[32] R. Rathee and P. Rajain, "Online shopping environments and consumer's Need for Touch," J. Adv. Manag. Res., 2019, doi: 10.1108/JAMR-12-2018-0116. 